\title{
Influence of Drip irrigation with Deficit Irrigation Levels and Planting Layouts on Performance of Turmeric (Curcuma longa L.)
}

\author{
S. D. Rathod ${ }^{1 *}$, J. H. Kadam ${ }^{2}$, D. K. Kathmale ${ }^{1}$ and M. D. Mali ${ }^{1}$ \\ ${ }^{1}$ Agricultural Research Station, Mahatma Phule Krishi Vidyapeeth, Kasbe Digraj, \\ Sangli- 416 305, Maharashtra, India \\ ${ }^{2}$ Dr. Balasaheb Sawant Konkan Krishi Vidyapeeth, Roha, Raigad- 402 109, \\ Maharashtra, India \\ *Corresponding author
}

\section{A B S T R A C T}

\section{Keywords}

Deficit irrigation, Drip Irrigation,

Irrigation levels,

Planting layout,

Turmeric yield and

Economics

Article Info

Accepted:

10 September 2020

Available Online:

10 October 2020
Field experiments were conducted at Agricultural Research Station, Mahatma Phule Krishi Vidyapeeth, Kasbe Digraj, Dist. Sangli, Maharashtra, India during 2014-15 to 2016-17 to study the influence of drip irrigation with deficit irrigation levels and planting layouts on yield of turmeric. Three planting layout $\left\{D_{1}: 2\right.$ crop lines $(30 \times 30 \mathrm{~cm})$ on raised beds of $1.2 \mathrm{~m}$ spacing and $0.6 \mathrm{~m}$ top width, $\mathrm{D}_{2}: 3$ crop lines $(22.5 \times 30 \mathrm{~cm})$ on raised beds of $1.2 \mathrm{~m}$ spacing and $0.6 \mathrm{~m}$ top width and $\mathrm{D}_{3}: 2$ crop lines $(37.5 \times 30 \mathrm{~cm})$ on both sides of $0.75 \mathrm{~m}$ spaced ridges and furrows $\}$ as main factor and six irrigation levels based on cumulative pan evaporation $(\mathrm{CPE})\left\{\mathrm{I}_{1}: 40 \% \mathrm{CPE}, \mathrm{I}_{2}: 35 \% \mathrm{CPE}, \mathrm{I}_{3}: 30 \% \mathrm{CPE}, \mathrm{I}_{4}: 25 \% \mathrm{CPE}, \mathrm{I}_{5}: 20 \% \mathrm{CPE}\right.$ and $\mathrm{I}_{6}$ : surface irrigation at $75 \mathrm{~mm} \mathrm{CPE}(1.0 \mathrm{IW} / \mathrm{CPE}$ ratios) $\}$ as sub-factor in split plot design were included for achieving objectives. The results revealed that drip irrigation with scheduling at alternate day of $40 \%$ CPE and planting of two rows at $37.5 \times 30 \mathrm{~cm}$ spacing on both sides of $0.75 \mathrm{~m}$ wide ridges and furrows resulted economically better production of fresh and dry rhizome yield with optimum use of water as it recorded significantly highest growth, yield and yield contributing parameters of turmeric. During water deficit condition, drip irrigation scheduled at alternate day of $35 \%$ and $30 \% \mathrm{CPE}$ and planting of two rows at $37.5 \times 30 \mathrm{~cm}$ spacing on both sides of $0.75 \mathrm{~m}$ wide ridges and furrows are also suggested for more turmeric production with less use of water.

\section{Introduction}

Turmeric is important spice crop cultivated for domestic consumption as well as export owing to its wide range of fields of utilities covering culinary to medicine. India ranks the first position in the world (Siddramappa, 2013) with an area of 1.90 lakh hectares and also produces 8.44 lakh tonnes (Anon., 2017).
India accounts for about 80 per cent of world turmeric production and 60 per cent of world exports. Whereas, Maharashtra is the second largest turmeric producing state in India after Telangana. Most of studies in turmeric were focused on to evaluate the medicinal value of turmeric and very few studies have been conducted on turmeric cultivation (Hermann and Martin, 1991; Ishimine et al., 2003). 
Improvement of crop cultivation technology for local climatic and edaphic factors is important for successful production of turmeric (Akamine et al., 1995; Ishimine et al., 2003). In view to this, proper planting layout and planting distance plays very crucial role to increase the yield and to decrease interference with weeds (Baki et al., 1995; Knezevic et al., 2003; Murphy et al., 1996). The optimum planting pattern for a specific root crop facilitates an optimum space to maximize vegetative parts, which subsequently receives higher solar energy and results in maximum yield. Adjusting raised beds and ridges-furrows along with row spacing is one of the important agronomic practices for increasing yield of a row crop and reducing the competition with weeds (Murphy et al., 1996; Wicks et al., 2003). Apart from planting layout, soil moisture also plays very important role for growing full potentiality of crop during the different growth stages. However, Indian farmers often over irrigate through increased irrigation frequency and subsequently high amount of applied water causing deleterious effect on the applied nutrients, water and soil properties. Considering water as the scarcest, yet a priceless farming resource, precision irrigation aims at prudent usage of water throughout the process of farming is important. Further, climate change and prevailing seasonal water deficit endeavours for improvement in agronomic practices for addressing the water deficit situation. Deficit irrigation is one such approach to reduce the water consumption. To apply deficit irrigation, drip irrigation system is the perfect method as it is used for precise application of water and nutrients directly at the plant's root zone at right time with right amounts to grow turmeric crop optimally. However, farmers reported feedback about problem of rhizome rot due to wet conditions maintained near rhizomes by frequent application of water through drip irrigation system. This might be due to the lack of proper irrigation scheduling and thereby applying excess quantity of water. These conditions emphasized the need of field trial for studying impact of both planting layout and different irrigation levels on yield of turmeric. Accordingly, an experiment was planned to conduct the "Influence of drip irrigation with deficit irrigation levels and planting layouts on performance of turmeric (curcuma longa L.)" at Agricultural Research Station (ARS), Turmeric Research Scheme (TRS), Kasbe Digraj, Tal. Miraj, Dist. Sangli (M.S.).

\section{Materials and Methods}

Experimental site was located at ARS, TRS, Kasbe Digraj, Sangli under Mahatma Phule KrishiVidyapeeth, Rahuriduring 2014-15 to 2016-17. Climatically this region falls under the semi-arid and plain zone with average annual rainfall of $380.28 \mathrm{~mm}$. The distribution of rain is uneven and is distributed over 22 to 49 rainy days. The annual mean maximum and minimum temperature ranges between $28.49^{\circ} \mathrm{C}$ to $38.43{ }^{\circ} \mathrm{C}$ and $11.61{ }^{\circ} \mathrm{C}$ to $21.75{ }^{\circ} \mathrm{C}$, respectively. The annual mean pan evaporation ranges from 3.04 to $6.68 \mathrm{~mm}$ day $^{-}$ 1 . Soil type observed at the experimental site was medium deep black clayey soil with alkaline in $\mathrm{pH}$ (8.20), low in available nitrogen (188.71 kg ha $\left.\mathrm{ka}^{-1}\right)$ and available phosphorus (9.90 kg ha ${ }^{-1}$ ) and very high in available potassium (437.96 kg ha $\left.\mathrm{ha}^{-1}\right)$. Experiment was laid in split plot design with three replications. The high yielding turmeric variety Salem was used for this experiment. Treatments were assigned as below:

\section{Main-plot: Planting layout}

$\mathrm{D}_{1}: 2$ crop lines $(30 \times 30 \mathrm{~cm})$ on raised beds of $1.20 \mathrm{~m}$ spacing and $0.60 \mathrm{~m}$ top width

$\mathrm{D}_{2}: 3$ crop lines $(22.5 \times 30 \mathrm{~cm})$ on raised beds of $1.20 \mathrm{~cm}$ spacing and $0.60 \mathrm{~m}$ top width 
$\mathrm{D}_{3}: 2$ crop lines $(37.5 \times 30 \mathrm{~cm})$ on both sides of $0.75 \mathrm{~m}$ spaced ridges and furrows

Sub-plot: Deficit Irrigation levels based on cumulative pan evaporation (CPE) through drip irrigation on alternate day

$\mathrm{I}_{1}: 40 \%$ CPE (Crop factors are not available for turmeric crops)

$\mathrm{I}_{2}: 35 \% \mathrm{CPE}$

$\mathrm{I}_{3}: 30 \% \mathrm{CPE}$

$\mathrm{I}_{4}: 25 \% \mathrm{CPE}$

$\mathrm{I}_{5}: 20 \% \mathrm{CPE}$

$\mathrm{I}_{6}$ : Surface irrigation at $75 \mathrm{~mm}$ CPE (1.0 IW/CPE ratios) i.e. IW/CPE means irrigation water/cumulative pan evaporation

The recommended dose of 25 ton farm yard manure $\mathrm{ha}^{-1}+200: 100: 100 \mathrm{NPK} \mathrm{Kg} \mathrm{ha}{ }^{-1}$ were applied for turmeric. Entire $\mathrm{P}_{2} \mathrm{O}_{5}$ and $\mathrm{K}_{2} \mathrm{O}$ were applied as basal dose at the time of planting. While Nitrogen was applied in two equal splits at 6 and 12 weeks interval starting from planting. Fertilizer were applied with Urea, DAP and MOP as source of the nutrients. The irrigation was provided at alternate day as per treatments through drip irrigation system (Emitters @ 4 lph and 0.60 $\mathrm{m}$ spacing between two emitters) with one lateral placed at the middle of each raised beds and ridges. All standard agronomic practices were followed uniformly across the treatments during the conduct of the experiment. Growth parameters of turmeric observed during the conduct of the experiment is expressed as leaf area $\left(\mathrm{cm}^{2}\right.$ plant $^{-1}$ ), height of plant (cm), Number (No.) of tillers per plant, No. of leaves per tiller at 150 DAP (days after planting). The yield and yield contributing parameters of turmeric i.e., weight of mother rhizome $\left(\mathrm{gm} \mathrm{plant}^{-1}\right)$, No. of primary rhizome per plant, weight of primary rhizome $\left.(\mathrm{gm} \mathrm{plant})^{-1}\right)$, No. of secondary rhizome per plant, weight of secondary rhizome $\left(\mathrm{gm} \mathrm{plant} \mathrm{t}^{-1}\right.$ ), curcumin $(\%)$, fresh rhizomes yield $\left(\mathrm{qha}^{-1}\right)$ and dry rhizomes yield $\left(\mathrm{qha}^{-1}\right)$ were recorded at harvest. Fresh rhizomes were harvested at maturity by digging. Fresh rhizome yield and dry rhizome yield presented is cumulative of all rhizomes harvested (Mother, primary, secondary and tertiary rhizomes). The economic feasibility of different treatment combinations were evaluated by cost of cultivation (Rs $\left.\mathrm{ha}^{-1}\right)$, gross returns $\left(\mathrm{Rs} \mathrm{ha}^{-1}\right)$, net profit $\left(\mathrm{Rs} \mathrm{ha}^{-1}\right)$ and $\mathrm{B}$ : C ratio. The split plot design with three main factors and six sub-factors with three replications were used for statistical analysis of growth, yield and economics of turmeric cultivation under different treatments (Panse et al., 1976).

\section{Results and Discussion}

Effect of drip irrigation with deficit irrigation levels and planting layouts on growth parameters of turmeric

The pooled data for the years 2014-15, 201516 and 2016-17 pertaining to growth parameters of turmeric as influenced by deficit irrigation, planting layout and density are presented in Table 1 . The significantly maximum pooled mean height of plant $(116.93 \mathrm{~cm})$ was observed in $\mathrm{D}_{3}$ i.e. two crop lines on the ridges and furrows. The pooled mean of highest number of tillers per plant were observed in $\mathrm{D}_{3}$ (2.98) layout which was at par with $\mathrm{D}_{1}(2.44)$ i.e. 2 crop lines $(30$ x 30 $\mathrm{cm}$ ) on raised beds of $1.2 \mathrm{~m}$ spacing and 0.6 $\mathrm{m}$ top width. The significantly higher pooled mean of number of leaves per tiller was observed in the $\mathrm{D}_{3}$ (11.90) which were followed by $\mathrm{D}_{1}$ (10.4). The effect of different deficit irrigation levels, planting layout and density on leaf area was found to be nonsignificant. Whereas, significantly lowest pooled mean of height of plant $(94.04 \mathrm{~cm})$, number of tillers per plant (1.86), number of leaves per tiller (9.0) and leaf area (188.87 $\mathrm{cm}^{2}$ ) were observed under $D_{2}$ i.e. 3 crop lines $(22.5 \times 30 \mathrm{~cm})$ on raised beds of $1.20 \mathrm{~m}$ 
spacing and $0.60 \mathrm{~m}$ top width. This might be due to more density of plants under $\mathrm{D}_{2}$ $\left(83,333\right.$ plants ha $\left.{ }^{-1}\right)$ than $\mathrm{D}_{1}(55,555$ plants ha $\left.{ }^{1}\right)$. Secondly, there were denser plant population due to three crop lines on just 0.6 $m$ top width of raised bed as compare to two crop lines on $0.75 \mathrm{~m}$ ridges and furrows. Hence, growth parameters of turmeric were recorded highest under $\mathrm{D}_{3}$.Hossain et al., (2005) found that the significantly lowest No. of tillers per turmeric plant was observed at $20 \mathrm{~cm}$ plant spacing than larger plant spacings. The No. of tillers per plant under plant spacing of 30, 40, 50 and $60 \mathrm{~cm}$ were at par with each other. The lower plant height was observed under plant spacing of $20 \mathrm{~cm}$ and at par with plant spacings of 30, 40, 50 and $60 \mathrm{~cm}$.

The scheduling of irrigation at $40 \% \mathrm{CPE}$ recorded significantly maximum pooled mean height of plant $(112.83 \mathrm{~cm})$, number of tillers per plant (3.0), number of leaves per tiller (10.5) and leaf area $\left(227.41 \mathrm{~cm}^{2}\right)$ followed by $35 \%$ CPE. Whereas, significantly lowest pooled mean height of plant $(96.07 \mathrm{~cm})$, number of tillers per plant (1.86), number of leaves per tiller (8.9) and leaf area (181.69 $\mathrm{cm}^{2}$ ) were recorded under 20\% CPE irrigation treatments. This might be due to that the fact that plants faced shortage of water (deficit water stress) in 20\% CPE as it was $50 \%$ less than the $40 \% \mathrm{CPE}$ treatments. On the contrary drip irrigation at $40 \%$ CPE might had facilitated better root aeration, field capacity conditions, nutrient and water availability for better development of turmeric plants due to application of right amount of water at right time and near root zone. The growth parameters were recorded significantly lower in surface irrigation treatment as compare to $40 \%, 35 \%$ and $30 \%$ CPE irrigation treatments under drip irrigation. This might be due to the high irrigation interval as compare to drip irrigation, loss of added nutrients through leaching, soils taken 2 to 3 days for coming back to field capacity after heavy irrigation at a time, runoff and other factors. The interaction effect of different deficit irrigation levels, planting layout and density on growth characters was found to be non-significant.

\section{Effect of drip irrigation with deficit irrigation levels and planting layouts on yield and yield contributing parameters of turmeric}

The pooled data for the years 2014-15, 201516 and 2016-17 pertaining to yield contributing parameters of turmeric as influenced by deficit irrigation, planting layout and density are presented in Table 2 and 3. The interaction effect of different deficit irrigation levels, planting layout and density was found to be non-significant on pooled mean of yield attributing characters except number and weight of secondary rhizomes and fresh rhizomes yield. The significantly highest pooled mean weight of mother rhizome/plant (81.10 gm), weight of primary rhizomes per plant (86.19 gm), No. of secondary rhizome per plant (12.4), weight of secondary rhizome per plant (428 gm) were observed under $\mathrm{D}_{3}$ i.e. i.e. two crop lines on the ridges and furrows followed by $\mathrm{D}_{1}$ and $\mathrm{D}_{2}$. The No. of primary rhizome per plant and curcumin (\%) were found non-significant under different planting layout. The significantly highest fresh (295.92 $\left.\mathrm{q} \mathrm{ha}^{-1}\right)$ as well as dry (61.93 $\left.\mathrm{q} \mathrm{ha}^{-1}\right)$ rhizome yield were recorded in the two crop lines on the ridges and furrows followed by 2 crop lines on raised beds of $1.20 \mathrm{~m}$ spacing and $0.60 \mathrm{~m}$ top width. Hence, the ridges and furrows of $0.75 \mathrm{~m}$ with $0.375 \times 0.30 \mathrm{~m}$ spaced turmeric treatment confirmed the previous recommendation given by Turmeric Research Station, Kasbe Digraj, Sangli. This might be due to the optimum plant density of 88,888 plants $\mathrm{ha}^{-1}$ in ridges and furrow system layout and lesser plant density of 55,555 plants $\mathrm{ha}^{-1}$ in 2 crop lines $(0.30 \times 0.30 \mathrm{~m})$ on raised beds of $1.20 \mathrm{~m}$ 
spacing and $0.60 \mathrm{~m}$ top width. Hossain et al., (2005) reported that when turmeric was planted at $20 \mathrm{~cm}$ spacing, rhizome could not expand properly, which ultimately resulted in the smaller rhizome compared with that planted with a larger spacing of $30 \mathrm{~cm}, 40 \mathrm{~cm}$ and 50 and $60 \mathrm{~cm}$ spacing. They further found that the yields recorded on ridges and furrows of $75,100,125$ and $150 \mathrm{~cm}$ with two crop lines were 724, 619, 478 and $354 \mathrm{gm} \mathrm{m}^{-2}$, respectively.

The largest shoot biomass and highest rhizome yield were obtained when turmeric was planted in two rows on the ridges with a $75 \mathrm{~cm}$ width followed by $100 \mathrm{~cm}$ width among the treatments (Hossain et al., 2005).The similar results were also observed in present study.

Among the different levels of deficit irrigation, the significantly highest pooled mean weight of mother rhizome/plant(74.1 gm), No. of primary rhizome per plant (2.97), weight of primary rhizome per plant (86.61 gm), No. of secondary rhizome per plant (11.6), weight of secondary rhizomes per plant (416.88 $\mathrm{gm})$, fresh as well as dry rhizome yield (264.79 $\mathrm{q} \mathrm{ha}^{-1}$ and $55.14 \mathrm{q} \mathrm{ha}^{-1}$, respectively) was recorded under scheduling of irrigation at $40 \% \mathrm{CPE}$ which was followed by scheduling of irrigation at $35 \% \mathrm{CPE}$. Whereas, the significantly lowest pooled mean of fresh as well as dry rhizome yield (175.05 q ha ${ }^{-1}$ and $35.67 \mathrm{q} \mathrm{ha}^{-1}$, respectively) was recorded under irrigation to $20 \% \mathrm{CPE}$ treatment.

This might be due to $40 \%$ CPE facilitated optimum moisture, better field capacity conditions, nutrient and water availability for better development of turmeric plants due to application of right amount of water at right time and near root zone. Selvarajet al., (1997) also reported highest water use efficiency in the treatment irrigating with drip at 0.36
IW/CPE ratio daily (it mean $36 \%$ of pan evaporation or cumulative pan evaporation) with highest yield. Whereas, shortage of water might have resulted lesser rhizome yield in $20 \%$ CPE with drip irrigation. Drip irrigated treatments at $40 \%, 35 \%$ and $30 \%$ $\mathrm{CPE}$ recorded more yields as compare to surface irrigation with ridges and furrows. Sadarunnisa et al., (2010) and Patel et al., (2012) obtained higher yields in drip irrigation over furrow irrigation.

Effect of drip irrigation with deficit irrigation levels and planting layouts on water requirement and water use efficiency of turmeric

The treatment wise water requirement $(\mathrm{mm})$, fresh rhizome yield $\left(\mathrm{q} \mathrm{ha}{ }^{-1}\right)$ and water use efficiency (kg/ha-mm) were shown in Fig. 1. It is observed from Fig. 1 that the water requirement of turmeric was recorded highest $(1350 \mathrm{~mm})$ under surface irrigation at $75 \mathrm{~mm}$ $\mathrm{CPE}$ (1.0 IW/CPE ratios) followed by scheduling of irrigation at 40\% CPE (562 $\mathrm{mm}$ ) on alternate day through drip irrigation.

The lowest water requirement $(323 \mathrm{~mm})$ and highest water use efficiency $(54.15 \mathrm{~kg} / \mathrm{ha}-$ $\mathrm{mm}$ ) were observed under drip irrigation on alternate day at $20 \%$ CPE. Thiyagarajan et al., (2011) also recorded $568.4 \mathrm{~mm}$ of water requirement for turmeric when drip scheduled daily at $40 \%$ PE. They also registered 1120 $\mathrm{mm}$ of water under surface irrigation. The lowest water use efficiency $(15.65 \mathrm{~kg} / \mathrm{ha}-\mathrm{mm})$ was recorded by surface irrigation at $75 \mathrm{~mm}$ CPE (1.0 IW/CPE ratios). The 40\% CPE treatment recorded $562 \mathrm{~mm}$ of water requirement and $47.16 \mathrm{~kg} / \mathrm{ha}-\mathrm{mm}$ of water use efficiency. Thiyagarajan et al., (2011) registered water use efficiency for turmeric of 22 and $47 \mathrm{~kg} / \mathrm{ha}-\mathrm{mm}$ under surface irrigation at $0.9 \mathrm{IW} / \mathrm{CPE}$ ratio and drip irrigation with $40 \%$ CPE, respectively. 
Table.1 Effect of deficit irrigation and planting layout on growth of turmeric

\begin{tabular}{|c|c|c|c|c|c|c|c|c|c|c|c|c|c|c|c|c|}
\hline \multirow[t]{2}{*}{ Treatment } & \multicolumn{4}{|c|}{ Height of plant (cm) } & \multicolumn{4}{|c|}{ No. of tillers per plant } & \multicolumn{4}{|c|}{ No. of leaves per tiller } & \multicolumn{4}{|c|}{ Leaf area $\left(\mathrm{cm}^{2}\right.$ plant $\left.^{-1}\right)$} \\
\hline & $\begin{array}{c}2014- \\
15\end{array}$ & $\begin{array}{c}\text { 2015- } \\
16\end{array}$ & $\begin{array}{c}2016- \\
17\end{array}$ & Mean & $\begin{array}{c}2014- \\
15\end{array}$ & $\begin{array}{c}2015- \\
16\end{array}$ & $\begin{array}{c}2016- \\
17\end{array}$ & Mean & $\begin{array}{c}2014- \\
15\end{array}$ & $\begin{array}{c}2015- \\
16\end{array}$ & $\begin{array}{c}2016- \\
17\end{array}$ & Mean & $\begin{array}{c}2014- \\
15\end{array}$ & $\begin{array}{c}2015- \\
16\end{array}$ & $\begin{array}{c}\text { 2016- } \\
17\end{array}$ & Mean \\
\hline \multicolumn{17}{|l|}{ Layout } \\
\hline $\mathbf{D}_{1}$ & 98.16 & 97.44 & 108.27 & 101.29 & 2.4 & 2.68 & 2.22 & 2.44 & 8.6 & 9.38 & 10.4 & 9.5 & 199.27 & 194.81 & 208.32 & 200.80 \\
\hline $\mathbf{D}_{2}$ & 93.50 & 91.69 & 96.93 & 94.04 & 1.7 & 2.16 & 1.76 & 1.86 & 8.5 & 9.08 & 9.5 & 9.0 & 194.39 & 188.61 & 183.62 & 188.87 \\
\hline $\mathbf{D}_{3}$ & 118.63 & 105.76 & 126.39 & 116.93 & 2.5 & 2.95 & 3.44 & 2.98 & 8.6 & 9.96 & 11.9 & 10.2 & 187.42 & 202.70 & 244.87 & 211.66 \\
\hline S. E. \pm & 3.81 & 4.63 & 1.96 & 2.55 & 0.11 & 0.07 & 0.08 & 0.19 & 0.17 & 0.22 & 0.15 & 0.33 & 6.44 & 4.74 & 4.61 & 10.37 \\
\hline CD at $5 \%$ & 11.65 & 13.39 & 5.65 & 7.38 & 0.34 & 0.21 & 0.23 & 0.54 & NS & 0.66 & 0.44 & 0.97 & NS & 13.69 & 13.32 & NS \\
\hline \multicolumn{17}{|l|}{ Irrigation } \\
\hline $\mathbf{I}_{1}$ & 112.47 & 105.80 & 120.21 & 112.83 & 2.9 & 2.98 & 3.10 & 3.00 & 9.4 & 10.5 & 11.4 & 10.5 & 228.56 & 220.92 & 232.76 & 227.41 \\
\hline $\mathbf{I}_{2}$ & 107.38 & 101.47 & 117.50 & 108.78 & 2.6 & 2.80 & 2.88 & 2.77 & 8.8 & 10.0 & 11.2 & 10.0 & 200.42 & 201.95 & 229.42 & 210.60 \\
\hline $\mathbf{I}_{3}$ & 103.33 & 98.60 & 113.38 & 105.10 & 2.2 & 2.69 & 2.62 & 2.51 & 8.5 & 9.6 & 10.8 & 9.6 & 188.14 & 192.90 & 213.56 & 198.20 \\
\hline $\mathbf{I}_{4}$ & 99.71 & 95.44 & 105.58 & 100.24 & 1.9 & 2.42 & 2.26 & 2.20 & 8.0 & 9.1 & 10.2 & 9.1 & 184.97 & 187.20 & 202.38 & 191.51 \\
\hline $\mathbf{I}_{5}$ & 96.58 & 92.07 & 99.56 & 96.07 & 1.5 & 2.27 & 1.82 & 1.86 & 8.3 & 8.7 & 9.6 & 8.9 & 171.83 & 182.89 & 190.33 & 181.69 \\
\hline$I_{6}$ & 101.11 & 96.40 & 106.96 & 101.49 & 2.1 & 2.42 & 2.18 & 2.22 & 8.4 & 8.9 & 10.3 & 9.2 & 188.23 & 186.36 & 205.18 & 193.26 \\
\hline S. E. \pm & 1.23 & 1.93 & 2.82 & 0.71 & 0.10 & 0.11 & 0.13 & 0.07 & 0.11 & 0.29 & 0.22 & 0.08 & 3.68 & 5.49 & 6.61 & 1.74 \\
\hline CD at $5 \%$ & 3.56 & 5.56 & 8.14 & 2.06 & 0.29 & 0.31 & 0.39 & 0.20 & 0.32 & 0.87 & 0.66 & 0.24 & 10.65 & 15.85 & 19.10 & 5.01 \\
\hline $\begin{array}{l}\text { Interaction } \\
\text { Effects }\end{array}$ & NS & NS & NS & NS & NS & NS & NS & NS & NS & NS & NS & NS & NS & NS & NS & NS \\
\hline
\end{tabular}

Note: $\mathrm{D}_{1:} 2$ crop lines $(30 \times 30 \mathrm{~cm})$ on raised beds of $1.20 \mathrm{~m}$ spacing and $0.60 \mathrm{~m}$ top width, $\mathrm{D}_{2:} 3$ crop lines $(22.5 \times 30 \mathrm{~cm})$ on raised beds of $1.20 \mathrm{~cm}$ spacing and $0.60 \mathrm{~m}$ top width, $\mathrm{D}_{3}: 2$ crop lines $(37.5 \times 30 \mathrm{~cm})$ on both sides of 0.75 m spaced ridges and furrows; $\mathrm{I}_{1:}$ 40\% CPE, $\mathrm{I}_{2}: 35 \% \mathrm{CPE}, \mathrm{I}_{3}: 30 \% \mathrm{CPE}, \mathrm{I}_{4}: 25 \% \mathrm{CPE}, \mathrm{I}_{5}: 20 \% \mathrm{CPE}$ and $\mathrm{I}_{6}:$ Surface irrigation at $75 \mathrm{~mm}$ CPE (1.0 IW/CPE ratios) 
Table.2 Effect of deficit irrigation and planting layout on yield and yield contributing characters of turmeric

\begin{tabular}{|c|c|c|c|c|c|c|c|c|c|c|c|c|c|c|c|c|}
\hline \multirow[t]{2}{*}{ Treatment } & \multicolumn{4}{|c|}{ Curcumin $(\%)$} & \multicolumn{4}{|c|}{$\begin{array}{l}\text { Weight of mother rhizome } \\
\left.\text { (gm plant }^{-1}\right)\end{array}$} & \multicolumn{4}{|c|}{$\begin{array}{c}\text { No. of primary rhizomes per } \\
\text { plant }\end{array}$} & \multicolumn{4}{|c|}{$\begin{array}{c}\text { Weight of primary rhizomes(gm } \\
\text { plant }^{-1} \text { ) }\end{array}$} \\
\hline & $\begin{array}{l}2014- \\
15\end{array}$ & $\begin{array}{l}2015- \\
16\end{array}$ & $\begin{array}{l}2016- \\
17\end{array}$ & Mean & $\begin{array}{l}2014- \\
15\end{array}$ & $\begin{array}{l}2015- \\
16\end{array}$ & $\begin{array}{l}2016- \\
17\end{array}$ & Mean & $\begin{array}{l}2014- \\
15\end{array}$ & $\begin{array}{l}2015- \\
16\end{array}$ & $\begin{array}{l}2016- \\
17\end{array}$ & Mean & $\begin{array}{l}2014- \\
15\end{array}$ & $\begin{array}{l}2015- \\
16\end{array}$ & 2016-17 & Mean \\
\hline \multicolumn{17}{|l|}{ Layout } \\
\hline $\mathrm{D}_{1}$ & 3.63 & 3.64 & 3.63 & 3.63 & 61.7 & 65.84 & 66.8 & 64.8 & 2.4 & 2.08 & 2.33 & 2.28 & 70.8 & 71.84 & 88.30 & 76.99 \\
\hline $\mathbf{D}_{2}$ & 3.64 & 3.62 & 3.63 & 3.63 & 57.1 & 49.02 & 62.0 & 56.1 & 2.0 & 1.82 & 1.93 & 1.90 & 54.1 & 52.73 & 78.24 & 61.70 \\
\hline $\mathbf{D}_{3}$ & 3.67 & 3.65 & 3.69 & 3.67 & 84.0 & 84.91 & 74.3 & 81.1 & 2.0 & 2.68 & 3.64 & 2.77 & 75.6 & 80.02 & 102.99 & 86.19 \\
\hline S. E. \pm & 0.009 & 0.01 & 0.01 & 0.006 & 2.87 & 1.77 & 0.77 & 3.74 & 0.08 & 0.08 & 0.10 & 0.29 & 2.31 & 2.77 & 1.77 & 1.76 \\
\hline CD at $5 \%$ & NS & NS & NS & NS & 8.70 & 5.13 & 2.21 & 10.79 & 0.25 & 0.24 & 0.30 & NS & 6.94 & 8.02 & 5.11 & 5.10 \\
\hline \multicolumn{17}{|l|}{ Irrigation } \\
\hline $\mathbf{I}_{1}$ & 3.69 & 3.68 & 3.67 & 3.68 & 77.8 & 72.8 & 71.8 & 74.1 & 2.6 & 3.0 & 3.34 & 2.97 & 82.0 & 79.7 & 98.16 & 86.61 \\
\hline $\mathbf{I}_{2}$ & 3.65 & 3.64 & 3.64 & 3.64 & 72.4 & 70.6 & 70.6 & 71.2 & 2.2 & 2.5 & 3.07 & 2.60 & 70.3 & 75.2 & 95.87 & 80.48 \\
\hline $\mathbf{I}_{3}$ & 3.66 & 3.63 & 3.67 & 3.65 & 69.6 & 66.3 & 68.8 & 68.2 & 2.1 & 2.1 & 2.71 & 2.32 & 68.7 & 68.5 & 91.53 & 76.24 \\
\hline $\mathbf{I}_{4}$ & 3.62 & 3.60 & 3.64 & 3.62 & 63.6 & 63.4 & 65.8 & 64.3 & 2.0 & 1.9 & 2.37 & 2.09 & 62.8 & 63.4 & 85.24 & 70.49 \\
\hline $\mathbf{I}_{5}$ & 3.61 & 3.63 & 3.65 & 3.63 & 58.2 & 62.4 & 63.1 & 61.2 & 1.8 & 1.8 & 1.91 & 1.83 & 52.0 & 60.0 & 81.20 & 64.40 \\
\hline $\mathbf{I}_{6}$ & 3.65 & 3.64 & 3.61 & 3.63 & 64.0 & 64.1 & 66.1 & 64.8 & 2.0 & 1.9 & 2.40 & 2.10 & 65.2 & 62.3 & 87.07 & 71.54 \\
\hline S. E. \pm & 0.02 & 0.01 & 0.01 & 0.008 & 2.27 & 2.03 & 1.16 & 0.65 & 0.08 & 0.09 & 0.14 & 0.06 & 2.53 & 2.64 & 2.58 & 1.10 \\
\hline CD at $5 \%$ & NS & NS & NS & NS & 6.57 & 5.92 & 3.35 & 1.87 & 0.26 & 0.26 & 0.40 & 0.18 & 7.60 & 7.62 & 7.46 & 3.17 \\
\hline $\begin{array}{l}\text { Interaction } \\
\text { Effects }\end{array}$ & NS & NS & NS & NS & $\mathrm{NS}$ & $\mathrm{NS}$ & NS & $\mathrm{NS}$ & $\mathrm{NS}$ & NS & NS & NS & $\mathrm{NS}$ & $\mathrm{NS}$ & $\mathrm{NS}$ & $\mathrm{NS}$ \\
\hline
\end{tabular}

Note: $\mathrm{D}_{1} 2$ crop lines $(30 \times 30 \mathrm{~cm})$ on raised beds of $1.20 \mathrm{~m}$ spacing and $0.60 \mathrm{~m}$ top width, $\mathrm{D}_{2 .} 3$ crop lines $(22.5 \times 30 \mathrm{~cm})$ on raised beds of $1.20 \mathrm{~cm}$ spacing and $0.60 \mathrm{~m}$ top width, $\mathrm{D}_{3} .2$ crop lines $(37.5 \times 30 \mathrm{~cm})$ on both sides of $0.75 \mathrm{~m}$ spaced ridges and furrows; $\mathrm{I}_{1}: 40 \% \mathrm{CPE}, \mathrm{I}_{2}: 35 \% \mathrm{CPE}, \mathrm{I}_{3}: 30 \% \mathrm{CPE}, \mathrm{I}_{4}: 25 \% \mathrm{CPE}, \mathrm{I}_{5}: 20 \% \mathrm{CPE}$ and $\mathrm{I}_{6}:$ Surface irrigation at $75 \mathrm{~mm}$ CPE (1.0 IW/CPE ratios) 
Table.3 Effect of deficit irrigation and planting layout on yield and yield contributing characters of turmeric

\begin{tabular}{|c|c|c|c|c|c|c|c|c|c|c|c|c|c|c|c|c|}
\hline \multirow[t]{2}{*}{ Treatment } & \multicolumn{4}{|c|}{$\begin{array}{c}\text { No of secondary rhizomes } \\
\text { per plant }\end{array}$} & \multicolumn{4}{|c|}{$\begin{array}{c}\text { Weight of secondary rhizomes } \\
\text { per plant } \\
\left({\left.\text { gm } \text { plant }^{-1}\right)}^{\text {a }}\right.\end{array}$} & \multicolumn{4}{|c|}{ Yield of fresh rhizomes $\left(q \mathrm{ha}^{-1}\right)$} & \multicolumn{4}{|c|}{$\begin{array}{l}\text { Yield od dry rhizomes } \\
\qquad\left(q \text { ha }^{-1}\right)\end{array}$} \\
\hline & $\begin{array}{l}2014 \\
-15\end{array}$ & $\begin{array}{l}2015- \\
16\end{array}$ & $\begin{array}{l}2016 \\
-17\end{array}$ & $\begin{array}{c}\text { Mea } \\
\mathbf{n}\end{array}$ & $\begin{array}{l}2014- \\
15\end{array}$ & $\begin{array}{l}2015- \\
16\end{array}$ & $\begin{array}{l}2016- \\
17\end{array}$ & Mean & $\begin{array}{l}2014- \\
15\end{array}$ & $\begin{array}{l}2015- \\
16\end{array}$ & $\begin{array}{l}2016- \\
17\end{array}$ & Mean & $\begin{array}{l}2014- \\
15\end{array}$ & $\begin{array}{l}2015- \\
16\end{array}$ & $\begin{array}{l}2016- \\
17\end{array}$ & Mean \\
\hline \multicolumn{17}{|l|}{ Layout } \\
\hline $\mathbf{D}_{1}$ & 9.7 & 9.03 & 10.1 & 9.6 & 315 & 307.59 & 361 & 328 & 201.04 & 193.99 & 217.63 & 204.22 & 42.22 & 39.41 & 44.51 & 42.05 \\
\hline $\mathbf{D}_{2}$ & 5.1 & 6.43 & 8.3 & 6.6 & 221 & 227.44 & 295 & 248 & 159.21 & 153.12 & 171.31 & 161.21 & 32.64 & 30.79 & 33.65 & 32.36 \\
\hline $\mathbf{D}_{3}$ & 13.0 & 11.22 & 13.2 & 12.4 & 406 & 403.63 & 474 & 428 & 313.94 & 280.61 & 293.22 & 295.92 & 65.93 & 57.54 & 62.31 & 61.93 \\
\hline S. E. \pm & 0.22 & 0.30 & 0.26 & 0.55 & 15.48 & 11.08 & 9.62 & 4.51 & 10.95 & 5.52 & 6.93 & 6.16 & 2.29 & 1.13 & 1.27 & 1.14 \\
\hline CD at $5 \%$ & 0.67 & 0.87 & 0.75 & 1.60 & 46.45 & 32.01 & 27.78 & 13.01 & 32.85 & 15.96 & 20.07 & 17.80 & 6.87 & 3.27 & 3.67 & 3.31 \\
\hline \multicolumn{17}{|l|}{ Irrigation } \\
\hline $\mathbf{I}_{1}$ & 11.6 & 11.2 & 12.1 & 11.6 & 411 & 402.31 & 437.22 & 416.88 & 277.63 & 248.41 & 268.32 & 264.79 & 57.98 & 50.77 & 56.67 & 55.14 \\
\hline $\mathbf{I}_{2}$ & 10.2 & 10.0 & 11.6 & 10.6 & 340 & 336.93 & 419.56 & 365.35 & 242.38 & 236.79 & 256.12 & 245.10 & 50.63 & 48.30 & 53.56 & 50.83 \\
\hline $\mathbf{I}_{3}$ & 9.2 & 9.1 & 10.9 & 9.7 & 316 & 314.42 & 390.33 & 340.10 & 233.02 & 208.83 & 235.51 & 225.79 & 48.67 & 42.56 & 48.76 & 46.67 \\
\hline $\mathbf{I}_{4}$ & 8.3 & 7.7 & 10.0 & 8.7 & 276 & 275.53 & 352.78 & 305.14 & 193.40 & 197.06 & 211.66 & 200.71 & 40.38 & 40.09 & 43.39 & 41.29 \\
\hline $\mathbf{I}_{5}$ & 7.6 & 7.4 & 8.7 & 7.9 & 251 & 275.67 & 325.67 & 287.85 & 177.35 & 166.80 & 180.98 & 175.05 & 37.03 & 33.82 & 36.16 & 35.67 \\
\hline$I_{6}$ & 8.5 & 7.9 & 9.9 & 8.7 & 290 & 272.47 & 334.78 & 291.67 & 224.57 & 197.55 & 211.72 & 211.28 & 46.87 & 39.96 & 42.39 & 43.07 \\
\hline S. E. \pm & 0.31 & 0.29 & 0.42 & 0.13 & 11.37 & 10.57 & 16.18 & 3.99 & 6.79 & 6.82 & 11.37 & 2.63 & 1.42 & 1.39 & 2.33 & 0.65 \\
\hline CD at $5 \%$ & 0.91 & 0.86 & 1.22 & 0.38 & 34.11 & 30.54 & 46.72 & 11.51 & 30.37 & 19.70 & 32.84 & 7.61 & 4.26 & 4.01 & 6.73 & 1.88 \\
\hline $\begin{array}{c}\text { Interaction } \\
\text { Effects S.E. } \pm\end{array}$ & NS & NS & NS & 0.32 & NS & NS & NS & 9.76 & NS & NS & NS & 6.45 & NS & NS & NS & NS \\
\hline CD at $5 \%$ & & & & 0.99 & & & & 30.08 & & & & 19.88 & & & & \\
\hline
\end{tabular}

Note: $\mathrm{D}_{1:} 2$ crop lines $(30 \mathrm{x} 30 \mathrm{~cm})$ on raised beds of $1.20 \mathrm{~m}$ spacing and $0.60 \mathrm{~m}$ top width, $\mathrm{D}_{2:} 3$ crop lines $(22.5 \mathrm{x} 30 \mathrm{~cm})$ on raised beds of $1.20 \mathrm{~cm}$ spacing and $0.60 \mathrm{~m}$ top width, $\mathrm{D}_{3}: 2$ crop lines $(37.5 \times 30 \mathrm{~cm})$ on both sides of $0.75 \mathrm{~m}$ spaced ridges and furrows; $\mathrm{I}_{1}: 40 \% \mathrm{CPE}, \mathrm{I}_{2:}: 35 \% \mathrm{CPE}, \mathrm{I}_{3}: 30 \% \mathrm{CPE}, \mathrm{I}_{4}: 25 \% \mathrm{CPE}, \mathrm{I}_{5}: 20 \% \mathrm{CPE}$ and $\mathrm{I}_{6}:$ Surface irrigation at $75 \mathrm{~mm}$ CPE (1.0 IW/CPE ratios) 
Table.4 Effect of deficit irrigation and planting layout on economics of turmeric cultivation

\begin{tabular}{|c|c|c|c|c|c|c|c|c|c|c|c|c|c|c|c|c|}
\hline \multirow[t]{2}{*}{ Treatment } & \multicolumn{4}{|c|}{ Cost of cultivation (Rs. ha $\left.{ }^{-1}\right)$} & \multicolumn{4}{|c|}{ Gross returns (Rs. ha $\left.{ }^{-1}\right)$} & \multicolumn{4}{|c|}{ Net profit (Rs. ha $\left.{ }^{-1}\right)$} & \multicolumn{4}{|c|}{ B:C ratio } \\
\hline & $\begin{array}{l}2014- \\
15\end{array}$ & $\begin{array}{l}2015- \\
16\end{array}$ & $\begin{array}{l}2016- \\
17\end{array}$ & Mean & $\begin{array}{l}2014- \\
15\end{array}$ & $\begin{array}{l}2015- \\
16\end{array}$ & $\begin{array}{l}\text { 2016- } \\
17\end{array}$ & Mean & $\begin{array}{l}2014- \\
15\end{array}$ & $\begin{array}{l}2015- \\
16\end{array}$ & $\begin{array}{l}2016- \\
17\end{array}$ & Mean & $\begin{array}{l}2014 \\
-15\end{array}$ & $\begin{array}{l}2015 \\
-16\end{array}$ & $\begin{array}{l}2016- \\
17\end{array}$ & Mean \\
\hline \multicolumn{17}{|l|}{ Layout } \\
\hline $\mathbf{D}_{1}$ & 275151 & 285722 & 295435 & 285436 & 295528 & 315277 & 400567 & 337124 & 20377 & 29555 & 105132 & 51688 & 1.07 & 1.10 & 1.35 & 1.17 \\
\hline $\mathbf{D}_{2}$ & 297895 & 308158 & 308835 & 304963 & 228468 & 246346 & 302846 & 259220 & -69426 & -61812 & -5990 & -45743 & 0.77 & 0.80 & 0.97 & 0.85 \\
\hline $\mathbf{D}_{3}$ & 340973 & 348066 & 355530 & 348190 & 461491 & 460355 & 560781 & 494209 & 120518 & 112289 & 205250 & 146019 & 1.35 & 1.32 & 1.57 & 1.41 \\
\hline S. E. \pm & 15633 & 10025 & 9329.9 & 1633.46 & 16023.1 & 9069.2 & 11441.1 & 7059.5 & 3185.3 & 1220.9 & 3770.8 & 5722.2 & - & - & - & - \\
\hline CD at $5 \%$ & NS & 28951.5 & 26943.3 & 4717.15 & 62904.4 & 26190.4 & 33039.7 & 20386.7 & 12505 & 3525.8 & 10889 & 16524.6 & - & - & - & - \\
\hline \multicolumn{17}{|l|}{ Irrigation } \\
\hline$I_{1}$ & 321359 & 328696 & 338506 & 329520 & 405837 & 406165 & 510030 & 440677 & 84478 & 77468 & 171524 & 111157 & 1.25 & 1.23 & 1.49 & 1.32 \\
\hline$I_{2}$ & 312028 & 324605 & 333008 & 323214 & 354441 & 386419 & 482037 & 407632 & 42413 & 61814 & 149029 & 84418 & 1.12 & 1.18 & 1.43 & 1.24 \\
\hline$I_{3}$ & 308975 & 316154 & 324985 & 316705 & 340721 & 340466 & 438876 & 373354 & 31746 & 24312 & 113891 & 56650 & 1.09 & 1.07 & 1.34 & 1.16 \\
\hline $\mathbf{I}_{4}$ & 298532 & 312059 & 316102 & 308898 & 282668 & 320700 & 390551 & 331306 & -15865 & 8641 & 74449 & 22408 & 0.93 & 1.02 & 1.23 & 1.06 \\
\hline$I_{5}$ & 293853 & 302902 & 304418 & 300391 & 259187 & 270536 & 325415 & 285046 & -34666 & -32366 & 20997 & -15345 & 0.87 & 0.88 & 1.05 & 0.93 \\
\hline$I_{6}$ & 293290 & 299475 & 302583 & 298450 & 328121 & 319670 & 381478 & 343090 & 34831 & 20195 & 78895 & 44640 & 1.11 & 1.06 & 1.26 & 1.14 \\
\hline S. E. \pm & 9806.1 & 12006.4 & 19915.6 & 919.1 & 9916.2 & 11124 & 20984.3 & 5580 & 2973 & 2443.9 & 4070.9 & 4661.7 & - & - & - & - \\
\hline CD at $5 \%$ & NS & NS & NS & 2654.24 & 28636.3 & 32124.2 & 60598.8 & 16114.1 & 8585.4 & 7057.6 & 11756 & 13462.2 & - & - & - & - \\
\hline $\begin{array}{c}\text { Interaction } \\
\text { S. E. } \pm\end{array}$ & 24020 & 29409.5 & 48783 & 2251.36 & 24289.7 & 27248.2 & 51400.7 & 13668.2 & 7282.3 & 5986.4 & 9971.5 & 11418.8 & - & - & - & - \\
\hline CD at $5 \%$ & NS & NS & NS & NS & NS & NS & NS & NS & 22441 & 18447 & 30728 & NS & - & - & - & - \\
\hline
\end{tabular}

Note: $\mathrm{D}_{1:} 2$ crop lines $(30 \times 30 \mathrm{~cm})$ on raised beds of $1.20 \mathrm{~m}$ spacing and $0.60 \mathrm{~m}$ top width, $\mathrm{D}_{2:} 3$ crop lines $(22.5 \times 30 \mathrm{~cm})$ on raised beds of $1.20 \mathrm{~cm}$ spacing and $0.60 \mathrm{~m}$ top width, $\mathrm{D}_{3}$ : 2 crop lines $(37.5 \times 30 \mathrm{~cm})$ on both sides of $0.75 \mathrm{~m}$ spaced ridges and furrows; $\mathrm{I}_{1}: 40 \% \mathrm{CPE}, \mathrm{I}_{2:}: 35 \% \mathrm{CPE}, \mathrm{I}_{3}: 30 \% \mathrm{CPE}, \mathrm{I}_{4}: 25 \% \mathrm{CPE}, \mathrm{I}_{5}: 20 \% \mathrm{CPE}$ and $\mathrm{I}_{6}:$ Surface irrigation at $75 \mathrm{~mm}$ CPE (1.0 IW/CPE ratios) 
Fig.1 Water requirement, fresh rhizome yield and water use efficiency of turmeric influenced by different deficit irrigation levels through drip irrigation

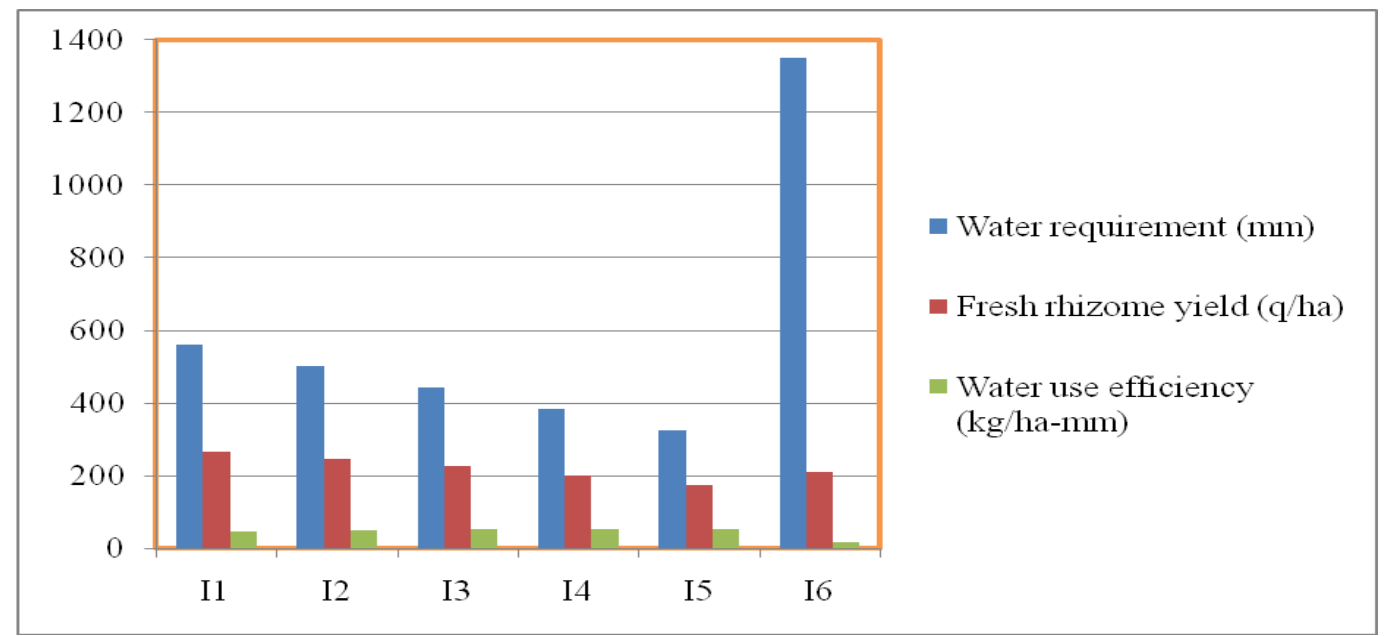

Economic feasibility of turmeric under drip irrigation with deficit irrigation levels and planting layouts

The pooled data for the years 2014-15, 201516 and 2016-17 pertaining to cost of cultivation of turmeric (Rs.ha ${ }^{-1}$ ) gross income $\left(\mathrm{Rs}^{-1} \mathrm{~h}^{-1}\right)$, net profit $\left(\mathrm{Rs} \mathrm{ha}^{-1}\right)$ and $\mathrm{B}: \mathrm{C}$ ratio induced under deficit irrigation, planting layout are presented in Table 4. The interaction effect of different deficit irrigation levels, planting layout on economic feasibility parameters was found to be non-significant. The maximum pooled mean of gross income (Rs.494209 ha-1), net profit (Rs.205250 ha-1) and $\mathrm{B}: \mathrm{C}$ ratio (1.41) was observed in $\mathrm{D}_{3}$ i.e. two crop lines on the ridges and furrows followed by $\mathrm{D}_{1}$ i.e. 2 crop lines $(0.30 \times 0.30$ $\mathrm{m})$ on raised beds of $1.2 \mathrm{~m}$ spacing and $0.6 \mathrm{~m}$ top width. This might be due to optimum plant density, highest rhizome yield and thereby more gross and net income obtained under ridges and furrows. Whereas, the lowest pooled mean of gross income (Rs.259220 ha ${ }^{-1}$ ), net profit (Rs.-45743 ha ${ }^{-1}$ ) and $\mathrm{B}: \mathrm{C}$ ratio $(0.85)$ was observed in $\mathrm{D}_{2}$ i.e. 3 crop lines on raised beds of $1.2 \mathrm{~m}$ spacing and $0.6 \mathrm{~m}$ top width. Three crop lines on just 0.6 $\mathrm{m}$ wider top of raised bed availed less space for rhizome growth under denser plant population as compare to two lines on raised bed as well as ridges and furrows. Consequently, $\mathrm{D}_{2}$ layout obtained lowest rhizome yield per plant, total rhizome yield per ha and thereby gained less gross and net income.

Among the different levels of deficit irrigation, significantly highest gross income (Rs.440677 ha $^{-1}$ ), net profit (Rs.111157 ha ${ }^{-1}$ ) and $\mathrm{B}: \mathrm{C}$ ratio (1.32) were recorded by scheduling of irrigation with drip at $40 \% \mathrm{CPE}$ followed by $35 \% \mathrm{CPE}$. The irrigation amount of $40 \%$ CPE provided optimum and congenial condition to plant growth and produced highest fresh and dry rhizome yield and finally the highest economic returns than other deficit irrigation treatments. Drip irrigation with $20 \%$ CPE produced lowest rhizome yield and thereby lowest gross and net income due to more water deficit situation arised in root zone.

In conclusions, drip irrigation with scheduling at alternate day of $40 \% \mathrm{CPE}$ and planting of two rows at $0.375 \mathrm{~m} \times 0.30 \mathrm{~m}$ spacing on both sides of $0.75 \mathrm{~m}$ wide ridges and furrows is recommended for maximum yield of 
turmeric, higher economic returns and efficient use of water over surface irrigation.

During water deficit condition, drip irrigation scheduled at alternate day of $35 \%$ and $30 \%$ $\mathrm{CPE}$ and planting of two rows at $37.5 \times 30 \mathrm{~cm}$ spacing on both sides of $75 \mathrm{~cm}$ wide ridges and furrows is suggested for efficient use of water and higher yield of turmeric.

\section{References}

Akamine, H., Ishimine, Y. and Murayama, S. (1995). Studies on characteristics and cultivation of turmeric (Curcuma longa L.). Effects of shading on the growth and yield of turmeric. Sci. Bull. Agr. Univ. Ryukyus. 42: 133-137.

Anonymous (2017).Spices wise area and production. Spices board of India, Ministry of commerce and industry, Government of India, Cochin. Retrieved from http://www.indianspices.com/ on 2705-17.

Amzad Hossain, Yukio Ishimine, Keiji Motomura and HikaruAkamine (2005). Effects of Planting Pattern and Planting Distance on Growth and Yield of Turmeric (Curcuma longa L.), Plant Production Science, 8(1): 95-105, DOI: 10.1626/pps.8.95.

Baki, B. B., Suhaimi, S. and Monir, J. A. (1995). Path analysis of two sympatric graminoids (Echinochloa crus-gallis pp. crus-galli (L.) Beauv. And Ischaemum rugosum salisb.) in competion with rice (Oryza sativa L. Var. MR84). Proc. APWSS 15: 546556.

Hermann, P. T. A. and Martin, A. W. (1991).Pharmacology of Curcuma longa.Planta Med. 57: 1-7.

Ishimine, Y., Hossain, M. A., Ishimine, Y. and Murayama, S. (2003). Optimal planting depth for turmeric (Curcuma longa L.) cultivation in dark red soil in Okinawa Island, Southern Japan. Plant Prod. Sci. 6: 83-89.

Knezevic, S. Z., Evans, S. P. and Mainz, M. (2003). Row space influences the critical timing for weed removal in soybean (Glycine max). Weed Tech 17: 666-673.

Murphy, S. D., Yakub, Y., Weise, S. and Swanton, C. J. (1996).Effect of planting patterns and inter-row cultivation on competition between corn (Zea mays) and late emerging weeds. Weed Sci. 44: 856-870.

Panse V. C. and Sukhatme P. V. (1967).Statistical methods for Agric. Workers. II. Enlarged Edn. ICAR, New Delhi.

Patel, D. K., Patel, B. M., Patel, P. T., Patel, D. M., Patel, B. J. (2012).Influence of irrigation methods along with nitrogen and potash management on yield and nutrient uptake by potato. Agric. Sci. Dig., 32 (1): 38-42.

Sadarunnisa, S., Madhumathi, C., Rao, G. S. and Sreenivasulu, B. (2010).Effect of fertigation on growth and yield of turmeric cv. Mydukur.J. Horti. Sci., 5(1): 78-80.

Selvaraj, P.K., Krishnamurthi, V.V., Manickasundaram, P., James Martin, G., Ayyaswamy, M. (1997).Effect of irrigation schedules and nitrogen levels on the yield of turmeric through drip irrigation. Madras Agricultural Journal 84, 347-348.

Siddramappa, S. (2013). Development schemes of spices. In: Symp. on Spices, Medicinal and Aromatic Crops SYMSAC- VII 'Post Harvest Processing of Spices and Fruit Crops, 27th - 29th November, 2013, Madikeri, Karnataka, pp. 162-172.

Thiyagarajan, G., Vijaykumar, M., Selvaraj, P. K., Duraisamy, V. K. and Yassin, M. M. (2011). Performance evaluation 
of fertigation of $\mathrm{N}$ and $\mathrm{K}$ on yield and water use efficiency of turmeric through drip irrigation. International Journal of Bio-resource and Stress Management-Chromatography, 2(1): 69-71

Wicks, G. A., Popken, D. H., Mahnken, G.
W., Hanson, G. E. and Lyon, D. J. (2003). Survey of winter wheat (Ttriticum aestivum) stubble fields sprayed with herbicides in 1998: Cultural practices. Weed Tech. 17: 467-474.

\section{How to cite this article:}

Rathod, S. D., J. H. Kadam, D. K. Kathmale and Mali, M. D. 2020. Influence of Drip irrigation with Deficit Irrigation Levels and Planting Layouts on Performance of Turmeric (Curcuma longa L.). Int.J.Curr.Microbiol.App.Sci. 9(10): 1202-1213. doi: https://doi.org/10.20546/ijcmas.2020.910.144 